\title{
INFLECTIONAL WORDS AND THEIR PROCESSES IN ENGLISH CHILDREN STORIES
}

\author{
Rudi Suherman $^{1}$, Lia Maulia Indrayani ${ }^{2}$, Ekaning Krisnawati ${ }^{3}$ \\ Padjadjaran University \\ ${ }^{1}$ rudi16005@mail.unpad.ac.id \\ ²lia.maulia@unpad.ac.id \\ 3ekaning@unpad.ac.id
}

\begin{abstract}
A Story is an effective media in nurturing language development particularly for children. A children story should be appropriated with its readers. One of its appropriateness indicator can be investigated by seeing its morphological aspect like inflectional words in it. This study is aimed at investigating the inflectional words and their types in English children story which may indicate its level of difficulty and its function. The descriptive qualitative study is employed embracing the characteristics of document analysis. The data taken from three different children stories which then are analyzed utilizing the inflectional theory proposed by Booij (2008). It is found that the verb inflection and adjective inflection, respectively, become predominant inflection that can be found on every story. It may indicate that children stories emphasize on process of doing and process of describing thing The finding is also drawn a conclusion that the length of the story is in line with the number of inflectional words.
\end{abstract}

Keywords: Inflectional words, Children story, Morphology.

\begin{abstract}
Abstrak
Dongeng merupakan media yang efektif dalam meningkatkan perkembangan bahasa terkhusus pada anak- anak. Sebuah dongeng anak mestilah disesuaikan dengan para pembacanya. Salah satu indikator kebersesuaian ini bisa ditelaah dari aspek - aspek morfologisnya, semisal dari keberadaan kata - kata infleksi. Penelitian ini bertujuan untuk menelaah kata - kata infleksi serta jenis - jenisnya di dalam dongeng bahasa inggris anakanak yang kemudian bisa dijadikan sebagai indikator tingkat kesulitan sebuah cerita serta mengetahui fungsi kata- kata infleksi tersebut dalam dongeng. Penelitian ini menerapkan metode kualitatif deskriptif dengan analisis dokumen sebagai pendekatannya. Data diambi dari beberapa dongen berbahasa Inggris yang kemudian dianalisis dengan menerapkan teori infleksi dari Booij (2008).Penelitian ini menunjukkan bahwa infleksi verba serta infleksi adjektiva,secara,berurutan, merupakan jenis infleksi yang paling banyak ditemukan. Hal ini menunjukan bahwa cerita anak lebih menitikberatkan pada penggambaran serta prilaku dari sang tokoh yang ada dalam cerita.. Selain itu, panjang pendeknya cerita berbanding lurus dengaan jumlah kata- kata infleksinya.
\end{abstract}

Kata Kunci: kata-kata Infleksional, Dongeng anak-anak, Morfologi. 


\section{A. INTRODUCTION}

The communication is the basic of survival besides water, food and shelter (Hunt, 1990 in Latifah, 2014). So, we communicate in any place and any time. Communication is one of the main functions of a language. One form of communication is an interaction between speakers. The interaction is facilitated by what are known as the communicative function of language. These functions change according to the situation. The form of language varies for different interaction (Latifah, 2014)

The interaction between human aims to convey a certain message .This Message can be delivered using two different ways: orally and in written form. The later way has variety of form such as memo, letter, newspaper, magazine, and story. Each type of written form serves different social function. Story which is usually categorized as narrative has social function to amuse, or convey a message to the reader with a different ways (Anderson, \& Anderson, 1997). By reading a story, a reader may be able to identify what message that the reader want to accomplish. Story can also create based on factual information or imaginary information.

Story has also been a fundamental part in every culture in the world. It is always derived from one generation to the next generation. Story always contains several values of life that make people think, reflect or even find the valuable lesson from it. Therefore, story always has its fans based regardless the ages, adult or children (Hamilton, 2014). Story is predominantly written for young children. Hence, there is type of story called children story. This type of the story is intentionally created for various reasons. Firstly it is generally believed as the media to convey certain values of culture for the student, secondly, it is also used to foster children first language development or as vehicle for language learning (Damayanti, 2017).

Each of the story written by the author has its language features. According to Anderson \& Anderson ( 1997 : 8) Language features in story Narrative text in particular usually found are specific characters, time word that connect event to tell when they occur, verb to show the action that occur in the story, and descriptive words to portray the characters and setting. Those language features are manifested in word in which become the mainly concern in the linguistic study particularly morphology.

As one of the linguistics branch, Morphology is assumed as the oldest branch of linguistics as the first linguist were primarily morphologist (Haspelmarth \& Sim, 2010). There are several Morphology definitions proposed by scholars. Haspelmarth and Sims ( $2010: 18$ ) defines morphology as the study of internal structure of words whereas Booij(2008) claims that morphology as the grammar of words .both definition serve the save item which primarily focus on words and how a word is constructed in certain rules that govern. 
As the study of word, morphology exhibits the word formation or word creation through a variety or process (Mc Carty, 2002). The two major concern of those process are derivational process and inflectional process. Derivational process or the term derivation is used for all aspects of word - structure involving affixation that is not inflectional Whereas Inflectional process change neither part of speech nor meaning, but only refine and give extra grammatical information ( Mc Carthy 2002, p. 44).

Formulation of the study is required in every research. It aim to be the guideline of a particular research. In addition, it is also known as research questions. In this study, the researcher propose a research question "what are the type of inflectional process found in children story.

\section{B. RESEARCH METHOD}

This study employs descriptive qualitative method in which the data gain from the children story will be analyzed and interpreted according to the inflectional theory in morphology. The data collection is important in conducting research. The data collection method in this study follows several sequencing steps as follows;

1. The compilation of children stories is read.

2. Three different stories are then selected as the data sources.

3. Each story is read carefully.

4. The inflection found in the story is underlined and collected.

5. Each inflection word is categorized based on its type,

6. The inflection words are interpreted, and the conclusion is drawn based on the inflection theory.

\section{Data Source}

Data collection is the process of collecting certain kind of information, of the object of the research such as age, gender, ethnicity or scores from a certain test. In data collection, it is contain data source of where is the data that will be analyzed is taken. In this study, the data taken from different English children story. The stories are taken from $A$ story a day: 365 stories to share. It is children stories that rewrite and compile by Miles Kelly, a prolific children author. There are three different stories that need to be analyzed, they are the young giants, the Bremen town musicians and the donkey and its shadow. The story is about $100-300$ word- long. Those stories are written for children whose age between $7-12$ years old in English as a foreign language country.

\section{FINDING AND DISCUSSION}

The objective of this research is to find out the type of inflection that can be found in children story. There are three different children stories that have been 
analyzed. The result of the analysis have found that there are 58 inflection words distributing in 3 stories. The data as presented below;

Table no. 3.1 the Distribution of Inflection on Each Story

\begin{tabular}{|c|c|c|c|}
\hline NO & $\begin{array}{l}\text { THE } \\
\text { GIANT }\end{array}$ & $\begin{array}{l}\text { THE BREMEN } \\
\text { TOWN MUSICIAN }\end{array}$ & $\begin{array}{l}\text { THE DONKEYS AND } \\
\text { ITS SHADOW }\end{array}$ \\
\hline 1 & Lived & Homes & Years \\
\hline 2 & Bigger & Decided & Hired \\
\hline 3 & Called & Musicians & Blazed \\
\hline 4 & Scooped & Looked for & Blows \\
\hline 5 & Years & Things & Heels \\
\hline 6 & Returned & Overbalanced & \\
\hline 7 & Amazed & Crashed & \\
\hline 8 & Realized & Youngest & \\
\hline 9 & Parents & Caused & \\
\hline 10 & Decided & Tiptoed & \\
\hline 11 & Travelled & Pushed & \\
\hline 12 & Agreed & Coals & \\
\hline 13 & Started & Cried & \\
\hline 14 & Farmhands & Scratched & \\
\hline 15 & Started & Claws & \\
\hline 16 & Stayed & Stabbed & \\
\hline 17 & Workers & Screeched & \\
\hline 18 & Horses & Wailed & \\
\hline 19 & Carts & Dared & \\
\hline 20 & Logs & Suited & \\
\hline 21 & Ripped & Lived & \\
\hline 22 & Tossed & Days & \\
\hline 23 & Pulled & & \\
\hline 24 & Happiest & & \\
\hline 25 & Miles & & \\
\hline
\end{tabular}

TOTAL 25 inflectional words 22 inflectional words 5 inflectional words

It can be seen from the table above, there are 58 inflectional words which are distributed into three different stories. Story number one with the title Young Giant has 25 inflectional words, the Bremen town musician as the second story has 22 inflectional words, the third story the donkey and its shadow has 6 inflectional word. Those data found are then distributed based on its inflectional type; verbs, noun, and adjective in the following tables bellows

\section{Table no 3.2 the Distribution of Inflectional Word Based on its Type in Young} Giant 


\begin{tabular}{|c|c|c|c|}
\hline NO & TYPE OF INFLECTION & & \\
\hline & Verb & Noun & Adjective \\
\hline 1 & Lived & Years & Bigger \\
\hline 2 & Called & Farmhands & Happiest \\
\hline 3 & Scooped & Workers & Miles \\
\hline 4 & Returned & Horses & \\
\hline 5 & Amazed & Carts & \\
\hline 6 & Realized & Logs & \\
\hline 7 & Decided & Parents & \\
\hline 8 & Travelled & & \\
\hline 9 & Agreed & & \\
\hline 10 & Started & & \\
\hline 11 & Started & & \\
\hline 12 & Stayed & & \\
\hline 13 & Ripped & & \\
\hline 14 & Tossed & & \\
\hline 15 & Pulled & & \\
\hline TOTAL & 15 words & 7 words & 3 words \\
\hline
\end{tabular}

As it can be seen on the above table, there are 25 different inflectional words, those words are distributed into three different types of inflection; verb, adjective and noun. Verb inflection become the dominant inflection type in this data. There are 15 verb inflection, 7 noun inflection, and 3 adjective inflection.

Table no.3.3 The Distribution of Inflectional Word based on its Type in The Bremen Town Musician

NO. TYPE OF INFLECTION

\begin{tabular}{l|lll}
\hline $\mathbf{1}$ & Verbal & Nominal & Adjectival \\
$\mathbf{2}$ & Decided & Homes & Youngest \\
$\mathbf{3}$ & Looked for & Musicians & \\
$\mathbf{4}$ & Overbalanced & Things & \\
$\mathbf{5}$ & Crashed & Coals & \\
$\mathbf{6}$ & Caused & Claws & \\
$\mathbf{7}$ & Tiptoed & Days & \\
$\mathbf{8}$ & Pushed & & \\
$\mathbf{9}$ & Cried & & \\
$\mathbf{1 0}$ & Scratched & & \\
$\mathbf{1 1}$ & Stabbed & & \\
$\mathbf{1 2}$ & Screeched & & \\
\end{tabular}




\section{$13 \quad$ Dared \\ $14 \quad$ Suited \\ $15 \quad$ Lived}

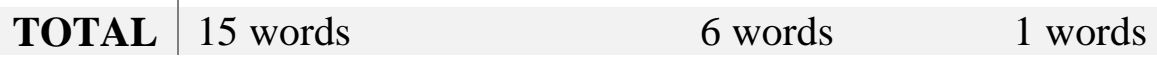

As can be seen on the table above, there are 22 inflectional words and they are distributed into three different types; verb inflection, noun inflection, and adjective inflection. Verb inflection become the most predominant inflection found in this data, there are 15 verb inflections, the second type of inflection that can be found, there are 6 noun inflection, and only one adjective inflection.

Table no 3.4 the Distribution of Inflectional Word Based on its Type in the donkey and its shadows.

\begin{tabular}{l|lll}
$\mathbf{N O}$ & TYPE OF INFLECTION & & \\
\hline $\mathbf{1}$ & Verb & Noun & Adjective \\
$\mathbf{2}$ & Hired & Heels & \\
$\mathbf{3}$ & Blazed & & \\
$\mathbf{4}$ & Blows & & \\
$\mathbf{5}$ & Fighting & 1 word
\end{tabular}

In the third story, the donkey and its shadows, there are only a few of inflectional words found. Consisting of 5 verb inflections, and 1 noun inflection. In this story, there is no adjective inflection can be found.

\section{DISCUSSION}

Due to the time limit and the numerous data, the data will be collected using bibliography technique and purposive random sampling. This technique can represent the majority tendency of data which then the conclusion can be drawn.

\section{Verb inflection}

Verb inflection is the inflectional process that takes place in verb marking, Verb inflection can be manifested into tense (present, past, future), Aspect(imperceptive, perfective etc.), Mood ( indicative, subjunctive, imperative etc.), Voice (active, passive etc. ), Number (singular, plural etc.) person ( first , second, third ), Gender. The following table cards are some of the examples of verb inflection taken from the sample.

\section{Datum 1}

Word : lived

Sentence: many years ago, There lived a farmer and his wife. 
Story :the young giant

The word lived belongs to verb inflection. The root of its morpheme is live as in present tense, meaning "to continue to be a live or have a life ". Inflectional process doesn't change the syntactic categories and meaning, but only refine and give extra grammatical information. Therefore, lived has the same meaning with live, there is only an additional bound morpheme or suffix - $e d$ to the word live. Since there is a time marker years ago which indicate past event. Consequently, the sentence is grammatically obligated to change into past tense and it is indicated by the inflectional process of the doer live that becomes lived. This words belongs to regular verbs its alteration following the suffixation of $d$ or $e d$ which is predictable phase or template.

\section{Datum 2}

Word : decided

Sentence : A donkey, a cat, and a dog, and a cockerel left their homes and decided to go to Bremen to become musicians.

Story : the Bremen town musician

The word decided belongs to verb inflection sample. The root of its morpheme is decide as in present tense, meaning "to choose something, especially after thinking carefully about several possibility “. Since inflectional process doesn't change the syntactic categories and meaning. Hence, the word decided has the same meaning and the same syntactic categories with decide there is only an additional bound morpheme or suffix - ed to the word decide. There is no specific time marker in this example. However, the type of this text is narrative which has specific tense that is past tense which indicate past event. Therefore, the sentence is grammatically obligated to change into past tense and it is indicated by the inflectional process of the doer decide that becomes decided. This words belongs to regular verbs in which its alteration following the suffixation of $-d$ or $-e d$ which is predictable phase or template.

\section{Noun inflection}

Noun inflection can be manifested into four different categories, number, case, definiteness, and gender. In English Inflection, Number and case tend to be the highest frequencies that may exhibit in written or spoken form. Number or plural noun in English basically comprises the base or stem plus the plural morpheme. The 
following table cards are some of the example of noun inflection taken from the sample.

\section{Datum 3}

Word : years

Sentence : He fed him up for six years until he too became a big strong giant.

Story : The young giants

The word years belongs to Noun Inflection which has meaning "a period of twelve months especially from January $1^{\text {st }}$ to December $31^{\text {st } ~ " . ~ T h e ~ w o r d ~ y e a r s ~ i s ~}$ originally from the simplex word year as it cannot be decomposed any further into smaller meaning unit. Afterward, there is a suffixation process of adding suffix $-s$ to the word year. It becomes years. This happened, as the word year must concord with other sentence elements especially the numerative marker six. The word years becomes complex word which consists of free morpheme (simplex word) year and suffix $-s$. This $-s$ indicates basic grammatical categories for plurality. The meaning and the syntactic categories of both words, year and years are the same.

\section{Datum 4}

Word : heels

Sentence: the donkey shed its cargos, took its heels and was soon out of sight.

Story :The donkey and its shadow

The word heels belongs to Noun Inflection which has a meaning "the raised part of part at the back of a shoe ". The word heels is originally from the simplex word heel as it cannot be decomposed any further into smaller meaning unit. Afterward, there is a suffixation process of adding suffix $-s$ to the word heel. It becomes heels. This happened, as the word heel must concord with other sentence element especially the countable marker cargos. The word heels becomes a complex word which consists of free morpheme (simplex word) heel and suffix $-s$. This $-s$ indicates basic grammatical categories for plurality. The meaning and the syntactic categories of both words, heel and heels, are the same.

\section{Adjective inflection}

Adjective can be inflected into several marking points, it is dominantly in degree of comparison. The category degree for adjective comprises the positive, 
comparative, and superlative degree. The following table cards are some of the example of adjective inflection taken from the sample.

\section{Datum 5}

Word : youngest

Sentence : but the youngest robber crept back to see what has caused the noise.

Story : the Bremen Town musician

The word youngest belongs to adjective Inflection which has a meaning "having lived for existed for only a short time and not old ". The word youngest is originally from the simplex word young as it cannot be decomposed any further into smaller meaning unit. Afterward, there is a suffixation process of adding suffix - est to the word young. It becomes youngest. This happened, as the word young must concord with other sentence element especially the implicit superlative elements .The word young becomes complex word which consists of free morpheme ( simplex word ) young and suffix -est. this indicate basic grammatical categories for superlative.

The syntactic categories of both word are the same.

\section{Datum 6}

\section{Word : bigger}

Sentence: they had a son who was bigger than a thumb.

Story : the young giant.

The word bigger belongs to adjective Inflection which has a meaning "large in size of amount ". The word bigger is originally from the simplex word big as it cannot be decomposed any further into smaller meaning unit. Afterward, there is a suffixation process of adding suffix $-e r$ to the word big. It becomes bigger. This happened, as the word big must concord with other sentence element especially the comparative word than. The word bigger becomes complex word which consists of free morpheme ( simplex word ) big and suffix - er. This indicates basic grammatical categories for comparative. The syntactic categories of both words are the same.

Among the inflection words found in the story, most of them include suffixion process especially suffix, only a few of them which involve prefix. One of the example as follow:

\section{Data 7}

\section{Word : Unimportant}

Sentence : If you quarrel about something that is unimportant, you may well lose what is important

story: The donkey and its shadow 
The word unimportant belongs to adjective Inflection which has a meaning "not necessary or of great value ". The word unimportant is originally from the simplex word important as it cannot be decomposed any further into smaller meaning unit. Afterword, there is a suffixation process of adding prefix -un to the word important and It becomes unimportant. This happened, as the word important must concord with other sentence element especially the emphasis meaning of the word message of the story. The word unimportant becomes complex word which consists of free morpheme (simplex word) important and prefix - un. This indicates basic grammatical categories for comparative. The syntactic categories of both words are the same.

\section{E. CONCLUSION}

Study has revealed that inflectional process take place in the children stories. There are three major inflectional can be found: Verb inflection to show past tense, noun inflection to show plurality, and adjective inflection to show comparison. Among those three inflectional types, verb inflection and adjective inflection are highly likely to be most frequent inflections that appear. It may indicate that children story emphasize on process of doing and process of describing thing. Besides, the length of the story is in accordance with the number of inflectional words can be found. The longer the story, the more the inflectional word could be found and the more difficult it becomes.

\section{REFERENCES}

Anderson, M. \& Anderson, K. 1997.Text Types in English 2. Melbourne: Macmillan Education Australia.

Booij Geert. 2006. The Grammar of Words: An introduction to Linguistic Morphology Oxford: Oxford University Press.

Carstairs, A\& -McCarthy. 2002. An Introduction to English Morphology: Word and their structure. Edinburgh: Edinburgh Press.

Damayanti, I. K. 2017. From Story Telling to Story writing, The Implementation of Reading to Learn ( R2L) Pedagogy to Teach English as a Foreign Language in Indonesia. Indonesian Journal of Applied Linguistics, Vol. 6 No.2, January 2017, pp. $229-242$.

Fromkin. 2003. An introduction to a language. Boston: Wadsworth.

Hanif, B. 2015. The Analysis of Word Formation of Soccer Terms in the Jakarta Post's articles. Unpublished Bachelor Thesis. UIN Syarif Hidayatulloh, Jakarta, Indonesia.

Haspelmath, M \& Sim, A. D. 2010.Understanding Morphology $2^{\text {nd }}$ Edition .London : Hodder Education. 
Janseen, M. 2005. Between Inflection and Derivation: Paradigmatic Lexical Function in Morphological Data Based. ILTEC, Lisboa, Portugal.

Josiah,U.E \& Udoudom ,J. C. 2012. Morphonemic Analysis of Inflectional Morphemes in English and Ibibio Noun: Implication for Linguistic study. Journal of Education and Learning: Vol. 1 No. 2, 2012.,pp $72-81$.

Jovanoic, V. Z. 2005. Morphological Aspects of English Adjectival Compounds : Corpus Analysis. Linguistics and Literature Vol 3. No.2, 2005,pp 209 -226..

Latifah, I. F.H. 2010. The Effectiveness of Role Play Method on Enhancing Speaking Skill in EFL Classroom (An Experimental Study at SMAN 1 Soreang Kab. Bandung). Unpublished Bachelor Thesis. STKIP Persatuan Islam, Bandung, Indonesia.

Hamilton, R. 2014. Bed time story in English: Field-Testing comprehensible input materials for natural second-language acquisition in Japanese Pre-school children. Downloaded from journal of international education research volume 10 , no.3. 